\title{
Patient-prosthesis mismatch did not impact postoperative course and hemodynamics after biosthetic mitral valve replacement
}

\author{
Hajime Ichimura*, Tamaki Takano, Takamitsu Terasaki, Yuko Wada, Tatsuichiro Seto, Jun Amano \\ From 23rd World Congress of the World Society of Cardio-Thoracic Surgeons \\ Split, Croatia. 12-15 September 2013
}

\section{Background}

The clinical risk of patient-prosthesis mismatch (PPM) after mitral valve replacement (MVR) is still a matter of controversy. We investigated whether PPM in mitral bioprothesis affects the operative results or hemodynamic parameters.

\section{Methods}

From 2004 to 2012, 34 patients underwent MVR with bioprosthesis in our institution. Patient's age was $74 \pm$ 4 years old and male/female ratio was 23/11.

We implanted three valves; Epic Supra ${ }^{\circledR}$ (SJM, Minnesota) in $8(25 \mathrm{~mm} ; 5,27 \mathrm{~mm} ; 3)$, Mosaic ${ }^{\circledR}$ (Medtronic, Minneapolis) in 15 (25 mm; 5, $27 \mathrm{~mm} ; 8,29 \mathrm{~mm}$; 2), Carpentier Edwards Perimount ${ }^{(B)}$ (Edwards, Los Angeles) in 11 patients ( $25 \mathrm{~mm} ; 1,27 \mathrm{~mm} ; 8,29 \mathrm{~mm} ; 2)$. Sixteen patients (group $\mathrm{P}$ ) had small indexed effective orifice area (EOAI $\leq 1.2 \mathrm{~cm} 2 / \mathrm{m} 2$ ), and the remaining 18 patients (group N) had acceptable EOAI. We compared operative results and hemodynamic parameters recorded by echocardiography between both groups. We also evaluated correlation between predicted EOAI and hemodynamic parameters after MVR.

\section{Results}

Hospital mortality was $0 \%$ in both groups. Hospital stay was $26.5 \pm 15.6$ days in group $P$ and $34.2 \pm 20.7$ in group $\mathrm{N}$ (p:NS). There was no difference between both groups in postoperative EF ( $\mathrm{p}=0.92)$, max PG $(\mathrm{p}=0.38)$, mean PG $(\mathrm{p}=0.59)$, and measured EOAI from pressure half time $(\mathrm{p}=0.18)$. No correlation was found between predicted

* Correspondence: Ihajime@shinshu-u.ac.jp

Cardiovascular Surgery, Shinshu University, Matsumoto, Nagano, Japan
EOAI and measured EOAI $(\mathrm{R} 2=0.0011)$, mean PG $(\mathrm{R} 2=$ $0.0000)$ and $\max$ PG $(\mathrm{R} 2=0.0004)$.

\section{Conclusion}

PPM did not affect operative results and postoperative hemodynamics in biopsoethetic MVR. Smaller valve might be alternative when large bioprosthesis is difficult to implant.

Published: 11 September 2013

doi:10.1186/1749-8090-8-S1-0277

Cite this article as: Ichimura et al.: Patient-prosthesis mismatch did not impact postoperative course and hemodynamics after biosthetic mitral valve replacement. Journal of Cardiothoracic Surgery 2013 8(Suppl 1):0277.

Submit your next manuscript to BioMed Central and take full advantage of:

- Convenient online submission

- Thorough peer review

- No space constraints or color figure charges

- Immediate publication on acceptance

- Inclusion in PubMed, CAS, Scopus and Google Scholar

- Research which is freely available for redistribution

Submit your manuscript at www.biomedcentral.com/submit
() Biomed Central 